УДК 378.37.01.005.94.316.4

Кириченко Микола Олексійович

доктор філософії, член-кореспондент Академії наук вищої освіти України, ректор

ДВНЗ «Університет менеджменту освіти» НАПН України, м. Київ, Україна

ORCID ID 0000-0003-1756-9140

kmumo@umo.edu.ua

Отич Олена Миколаївна

доктор педагогічних наук, професор, проректор з науково-методичної роботи та міжнародних зв'язків ДВНЗ «Університет менеджменту освіти» НАПН України, м. Київ, Україна

ORCID ID 0000-0003-2686-2832

ndi-direktor@ukr.net

Олійник Віктор Васильович

доктор педагогічних наук, професор, дійсний член НАПН України, радник ректора

ДВНЗ «Університет менеджменту освіти» НАПН України, м. Київ, Україна

ORCID ID 0000-0002-2576-0722

vikt.oliynyk@gmail.com

\title{
ПРОБЛЕМИ І ПЕРСПЕКТИВИ РОЗВИТКУ ПІСЛЯДИПЛОМНОЇ ОСВІТИ В ІНФОРМАЦІЙНОМУ СУСПІЛЬСТВІ
}

\begin{abstract}
Анотація. Формування інформаційного суспільства як нової форми соціальної дійсності, що функціонує через посередництво мультизнаків - символів - сигналів - стимулів - кодів, стимулює всезростаючу інтелектуалізацію усіх видів суспільної практики, зокрема, освіти, яка перетворюється на теорію і практику неперервного професійного розвитку когнітивних працівників, здатних самостійно опрацьовувати інформацію і здобувати нове знання на основі використання інформаційно-комунікаційних технологій. Основними напрямами реформування освіти в Україні $\epsilon$ приведення іiі сутності і змісту у відповідність із сучасними світовими тенденціями іiі розвитку, зумовленими цивілізаційними змінами $\mathrm{i}$ викликами, а також набуття нею спроможності давати на них адекватні відповіді.

На основі узагальнення наукової літератури з проблеми розвитку освіти в інформаційному суспільстві й аналізу сучасних тенденцій розбудови системи післядипломної освіти в Україні у статті здійснено SWOT-аналіз розвитку цієї освітньої галузі в умовах ii інформатизації, індивідуалізації й інтеграції в європейський інформаційний освітній простір. Метою статті є визначення проблем, переваг, загроз і перспектив інформатизації вітчизняної післядипломної освіти і перетворення іiі на відкриту систему. За результатами дослідження зроблено висновок, що ефективне функціонування післядипломної освіти у відкритому інформаційному освітньому просторі забезпечується завдяки набуттю нею варіативності, гнучкості, здатності створювати оптимальні умови для індивідуалізації освітнього процесу на засадах поєднання формальної, неформальної та інформальної освіти. Доведено, що такі умови найбільш оптимально забезпечуються у відкритому університеті післядипломної освіти.

Визначено перспективні напрями й завдання розбудови національної системи відкритої післядипломної педагогічної освіти в Україні, запропоновано модель цього процесу: «цивілізаційна зміна - освітня проблема - пошук шляхів і розроблення програми іiі вирішення - відображення їх у змісті і формах ППО - акредитація і реалізація відповідних варіативних, диверсифікованих за змістом і профілями освітніх програм - моніторинг якості їх реалізації».
\end{abstract}

Ключові слова: післядипломна освіта; інформаційне суспільство; відкрита освіта; модернізація; інформатизація; інформаційні технології; SWOT-аналіз. 


\section{1. ВСТУП}

Постановка проблеми. Однією з найважливіших проблем Української держави на початку XXI століття є подолання системної соціально-економічної кризи і здобуття гідного місця в спільноті європейських країн. Досягнення цієї мети значною мірою зумовлюється успішністю розбудови в Україні інформаційного суспільства i утвердження економіки знань, в основу якої покладаються високоякісна освіта й фундаментальна наука, що грунтуються на використанні інформаційних технологій та широкому упровадженні інновацій i в перспективі зумовлять трансформацію інформаційного суспільства в суспільство знань.

Сучасне інформаційне суспільство характеризується зростанням ролі інформації і виробництвом інформаційних продуктів і послуг, що проникають в усі сфери життєдіяльності людини. Відбувається створення глобальної інформаційної інфраструктури, яка спрощує інформаційний обмін і доступ людей до інформації й тим самим сприяє задоволенню їхніх потреб в інформаційних продуктах і послугах.

В основу розвитку інформаційного суспільства покладається відповідна йому ідеологія, яка охоплює цінності, ідеї і погляди, що відображають ставлення людей до життя в інформаційному суспільстві, один до одного і слугують закріпленню, розвитку чи зміні відносин у цьому суспільстві.

Ідеологія інформаційного суспільства, що формується в сучасній Україні, визначає директиви людської діяльності у сферах:

- управління інформатизацією;

- управління людським капіталом, що зумовлює зростання числа спеціалістів у сфері IKT;

- управління інформаційно-комунікаційними технологіями, які сприяють підвищенню доступності інформації, скороченню цифрової нерівності та зростанню рівня комп'ютерної грамотності населення [1, с. 159-168].

Становлення в Україні ідеології інформаційного суспільства $\epsilon$ однією 3 найважливіших умов виходу iï із затяжних економічної i соціальної криз та забезпечення інноваційного розвитку суспільства і його соціальних інститутів, зокрема, освіти.

Аналіз останніх досліджень і публікацій. Проблемі становлення і розвитку інформаційного суспільства і його соціальних інститутів присвятили свої праці зарубіжні вчені й філософи (Й. Масуда, Т. Стоуньєр, М. Порат, Дж. Нейсбіт, Р. Катц, М. Маклюен, Д. Делл, О. Тоффлер, М. Кастельс, К. Хіяші), а також провідні філософи й науковці України (В. Андрущенко, В. Биков, О. Данильян, О. Дзьобань, Д. Дубов, С. Жданенко, В. Воронкова, Ю. Калиновський, О. Кивлюк, М. Кириченко, В. Кремень, В. Кушерець С. Мануйлов, Н. Моісеєв, О. Найдьонов, О. Прудникова, О. Пунченко, Д. Свириденко, О. Соснін та інші).

Цими дослідниками доведено, що формування інформаційного суспільства як нової форми соціальної дійсності, яка функціонує через посередництво мультизнаків символів - сигналів - стимулів - кодів, $\epsilon$ результатом розвитку інформаційновіртуальної реальності, що стимулює всезростаючу інтелектуалізацію усіх видів суспільної практики.

3 огляду на це, інформаційне суспільство вимагає від людини володіння новими компетентностями (цифровими, ІКТ-компетентностями, ІК-компетентностями) i специфічними - інформаційними - якостями, які уможливлять вироблення нею нових раціональних - методів обробки інформації і забезпечать успішність використання постійно оновлюваних інформаційних технологій. Сукупність таких інформаційних властивостей людини утворює іï інформаційну культуру, яка регулює інформаційні 
потреби людини, сприяє іiі адаптації до умов інформаційного суспільства і забезпечує успішність функціонування у ньому.

Інформаційна культура об’єднує в собі ідеї, погляди, парадигми, еталони взаємодії людини з інформацією й спрямовує іï на неперервне самовдосконалення на основі використання інформаційно-комунікаційних технологій, інформаційних матриць в усіх сферах людської життєдіяльності [1, с. 261 - 262].

Привертаючи увагу до принципово нових пріоритетів суспільства, що увійшло в інформаційний етап свого розвитку, сучасні вчені (В. Андрущенко, М. Згуровський, М. Кириченко та ін.) зазначають, що його головною цінністю $є$ не самі інформаційнокомунікаційні технології, а люди як творці й споживачі цих технологій. Тому, окрім технологічного виміру, інформаційне суспільство має конституювати себе в гуманітарному, мас-медійному, культурологічному та освітньо-науковому вимірах [1]; [2, с. 37]. У зв'язку з цим освіта в інформаційному суспільстві перетворюється на теорію і практику підготовки когнітивних працівників, які працюють зі знаннями й інформацією. На підтвердження цьому можна навести слова Президента НАПН України академіка В. Г. Кременя, який зазначає: «Наразі ніхто не заперечує, що основним капіталом сучасного суспільства $є$ людина, здатна до пошуку і засвоєння нових знань і прийняття нестандартних рішень...» [3, с. 5]. 3 огляду на це, освіта в інформаційному суспільстві набуває таких ознак:

- людський вимір знань (урахування того, що останні не можуть бути суто раціональними, а мають набути особистісного забарвлення, стати індивідуально значущими для людини);

- перетворення знань на інформаційний товар, якість якого залежить від творчого потенціалу особистості;

- інтернаціональний характер знань, внаслідок чого вони набувають глобального змісту й змінюють конфігурацію геополітичних сфер впливу у світі;

- міждисциплінарність, проблемна орієнтованість та інтегративність знань, що актуалізує значення їх фундаменталізації, здатності задовольняти потреби вирішення нових, нестандартних завдань;

- мережний характер процесу створення і розповсюдження нових знань, за якого головними його елементами стають вузли (окремі люди, групи людей, установи та організації) і гілки, що реалізують зв'язки між вузлами й розвиваються природно та довільно. У результаті формуються розгалужені мережі людей, установ та організацій (без кордонів), у яких відбувається створення нових знань й обмін ними, виробництво інтелектуальної продукції, проводяться фінансові операції, культурологічні обміни і ще величезна кількість інших видів взаємодії між людьми. Сучасні бази даних і бази знань у різних розділах науки відіграють роль гігантських «сховищ» для нескінченних фактів i базових істин, а глобальні комп'ютерні мережі стають потужними інструментами для високошвидкісного доступу до них з будь-яких куточків світу. За цих умов важливу роль відіграє уміння людини оперувати новим видом інформації - метаданими великими масивами, кластерами уніфікованих за певною ознакою даних і знань, здійснювати пошук і виокремлення метаданих зі світових інформаційних ресурсів, цілісно аналізувати їх під час виконання досліджень і розв'язання нових проблем [4, с. $5-6]$.

Невирішені аспекти проблеми. Визнаючи наукову доцільність і правомірність виокремлення вченими зазначених вище ознак освіти в інформаційному суспільстві, хочемо привернути увагу до того, що не менш важливою ознакою освіти в цьому суспільстві $є$ неперервність оволодіння фахівцем знаннями, оскільки це стає головною умовою формування в нього здатності оперативно і мобільно реагувати на перманентні змістові й технологічні зміни у своїй професійній сфері, відстежувати їх динаміку і не 
просто адаптуватися до них, а хоча б на крок їх випереджувати. Особливо це стосується професіоналів, які хочуть зберегти і розвинути свій фаховий рівень i конкурентоспроможність на сучасному ринку праці. Для того, щоб утриматися на професійній вершині, вони мають безперервно розвиватися і самовдосконалюватися упродовж усього професійного життя, черпаючи необхідні знання з інформаційного контенту. Це зумовило зміну освітньої парадигми індустріального суспільства («Освіта на все життя») на парадигму інформаційного суспільства («Освіта упродовж життя»«LongLifeLearning» (LLL) [5, с. 34] й тим самим актуалізувало необхідність посилення уваги до післядипломної освіти як освітньої галузі, що на практиці забезпечує реалізацію цієї парадигми як на рівні соціального замовлення суспільства, так і на рівні індивідуальних освітніх запитів фахівців.

Ефективне функціонування післядипломної освіти в інформаційному суспільстві вимагає переосмислення іiї мети і соціальної місії та перетворення іiі на відкриту освітню систему, що функціонує на засадах застосування мережних технологій; on-line освіти, електронної освіти, SMART-освіти, хмарних і туманних сервісів тощо. У зв'язку 3 цим метою нашої статті $\epsilon$ аналіз можливостей, перспектив і проблем розвитку післядипломної освіти в Україні в умовах іiі інформатизації, індивідуалізації, забезпечення ії̈ відкритості і компетентнісної спрямованості.

\section{2. МЕТОДИ ДОСЛІДЖЕННЯ}

У статті було використано комплекс методів дослідження: аналіз філософської і наукової літератури з проблем інформаційної революції, становлення і розвитку інформаційного суспільства та його соціальних інститутів, упровадження економіки знань, модернізації освіти, забезпечення іiі відкритості - для з'ясування ступеня теоретичної розробленості проблеми у сучасній науці; SWOT-аналіз - для виявлення переваг і проблем перетворення післядипломної освіти в Україні на відкриту систему, визначення перспектив і загроз у реалізації цього процесу.

\section{3. ТЕОРЕТИЧНІ ОСНОВИ ДОСЛІДЖЕННЯ}

Аналіз наукової літератури з проблем відкритої освіти (С. Антощук, В. Биков, мити В. Гравіт, М. Каку, С. Касьян, Л. Ляхоцька, В. Олійник, С. Полат та ін.) та післядипломної освіти (Г. Дмитренко, М. Кириченко, В. Маслов, В. Олійник, О. Отич, В. Пуцов, 3. Рябова та ін.) зумовлює висновок, що соціальною місією відкритої післядипломної освіти вчені вважають допомогу фахівцеві у постійному підтриманні робочої форми, належного професійного рівня, що забезпечує його ефективність та конкурентоспроможність на ринку праці.

Глобальною метою відкритої післядипломної освіти вони називають випереджувальну підготовку фахівців до повноцінної й ефективної участі в професійному i громадському житті в умовах швидкозмінного інформаційного суспільства.

Реалізація цієї мети забезпечується, на думку вчених, завдяки тому, що відкрита післядипломна освіта створює інноваційне навчально-пізнавальне середовище, центральною фігурою якого стає фахівець, який самостійно планує, програмує та реалізує проект власного професійного розвитку на засадах якнайповнішого розкриття свого творчого потенціалу й індивідуальних здібностей. Організація післядипломної освіти на основі принципу відкритості спонукає фахівця до неперервного розвитку своєї інформаційної культури та сприяє задоволенню його потреби в самостійному 
опануванні тими знаннями, які він вважає для себе найбільш актуальними.

\section{4. РЕЗУЛЬТАТИ ДОСЛІДЖЕННЯ}

Отже, система відкритої післядипломної освіти забезпечує оптимальні умови для індивідуалізації освітнього процесу на засадах поєднання формальної, неформальної й інформальної освіти. Причому, як зазначають вчені-футорологи, у перспективі остання набуде визначальної ролі і зумовить формування нової моделі освіти за принципом: «тільки ти - і комп'ютер». У цій моделі той, хто навчається чи підвищує свою кваліфікацію, зможе сам проектувати свою освітню траєкторію, обираючи навчальну програму відповідної складності й певного освітньо-кваліфікаційного рівня, визначаючи термін і обсяг змісту освіти, яку хоче отримати тощо. Так здобувачі післядипломної освіти стануть більш автономними й відповідальними. Як зазначає японський вчений-футуролог М. Каку, у найближчі 50 років заклади освіти стануть переважно віртуальними, а тих, хто буде відвідувати традиційні освітні заклади, будуть вважати невдахами, які не змогли сконструювати свою освіту.

3 огляду на це, заклади післядипломної освіти мають бути готовими відповісти на ці виклики, запровадивши консалтингові послуги для слухачів i надаючи їм рекомендації щодо проектування індивідуальної програми професійного розвитку на засадах гнучкого поєднання формальної, неформальної та інформальної освіти.

Зрозуміло, що ці питання варто розглядати не лише в організаційній i технологічній, але і в аксіологічній площині, оскільки вони пов'язані з проблемами взаємодії суб'єктів освітнього процесу, їхнього спілкування. А в інформаційному суспільстві воно буде реалізуватися не стільки як міжособистісна комунікативна взаємодія педагогів і тих, хто навчається (слухачів, курсантів, стажистів та ін.), скільки як їхній взаємозв'язок безпосередньо 3 комп'ютером або віртуальна консультація 3 провідними фахівцями галузі на основі використання SMART-технологій тощо. Це зумовлює необхідність не лише уточнення правил i норм професійної та комунікативної етики, але й вимагає переосмислення функцій і сутності самого спілкування в інформаційному суспільстві. Адже, незважаючи на те, що спілкування, за визначенням, $є$ процесом взаємозв'язку і взаємодії його учасників, під час якого відбувається обмін інформацією, емоціями, ставленнями, діяльністю та іії результатами, досвідом тощо, в інформаційному суспільстві воно все більше асоціюється лише 3 одним з його аспектів - комунікативним. Залишення поза увагою перцептивного та інтерактивного аспектів спілкування збіднює його сутність і зводить його лише до обміну інформацією між учасниками, у ході якого досягається порозуміння між ними. Але ж, нехтування афективним і практичним компонентами спілкування на користь гностичного може призвести у майбутньому до формалізації спілкування i «роботизації» його учасників, перетворення їх на убезособлені «вузли» глобальної інформаційної матриці.

Попри це застереження, слід визнати, що аргументів на користь упровадження в освітню практику системи відкритої післядипломної освіти більше, ніж аргументів проти цього і вони є досить переконливими. Це пояснюється тим, що система відкритої післядипломної освіти створює оптимальні умови для раціональної й економічно вигідної організації процесу підвищення кваліфікації, оскільки передбачає зменшення фінансових витрат і часу на оволодіння слухачами знаннями, дає їм змогу здобувати їх на робочому місці, й тим самим перетворює післядипломну освіту на мобільну, максимально гнучку й адаптовану систему [6].

В умовах відкритої освіти застосування сучасних способів оброблення, представлення та передачі інформації значно розширює можливості як системи 
післядипломної освіти, так i самих мереж, приводячи до створення нових інформаційних технологій, несподіваних комбінацій форм, методів і способів організації освітнього процесу. Наразі вимоги щодо використання їх усе більше спрощуються для користувачів, а освітньо-інформаційні послуги - стають все більш доступними та індивідуалізованими, що є надзвичайно актуальним для підвищення кваліфікації фахівців. Внаслідок цього нині все більшої популярності набуває різноманітне on-line навчання 3 використанням різних сертифікованих платформ (Coursera, EdEra, EdX, iTunes U, KhanAcademy Prometheus, Udemy та ін.) [7, с. 145], індивідуальних і групових форм навчання, інтерактивних тестів для перевірки успішності, форумів для обговорення ключових питань, проведення вебінарів та масових наукових заходів on-line тощо, які дають фахівцям можливість успішно навчатися, використовуючи найбільш зручний для них час, місце та обладнання: комп'ютер, ноутбук, планшет, смартфон та ін. За таких умов слухачам закладів післядипломної освіти немає потреби бути присутніми на навчальному занятті у певний час - вони можуть, не залишаючи робочого місця, прослухати потрібну лекцію чи переглянути майстер-клас викладача у записі в YouTube або в іншому зручному для них форматі.

3 метою забезпечення найбільш сприятливих умов для підвищення кваліфікації фахівців у закладах післядипломної освіти активно запроваджується очно-дистанційна та дистанційна форми навчання [7, с. 143-144], що сприяє:

- досягненню реальної, а не декларованої неперервності освіти і професійного розвитку;

- появі можливості задовольняти у міжкурсовий період інтереси та запити слухачів в отриманні змістовної інформації (блоки, модулі на Webcaйтах) та оперативно інформувати їх про нові розробки і перспективний педагогічний досвід;

- посиленню особистісної орієнтації навчання за рахунок забезпечення його індивідуалізації на основі застосування індивідуальних планів і графіків підвищення кваліфікації, які враховують рівень підготовки кожного слухача [6, с. 27].

Сучасні за змістом і зручні за часом оn-line заняття дають можливість кожному слухачеві самостійно проектувати своє навчання, виконання самостійних завдань і написання випускних робіт.

Для підтримки слухачів курсів підвищення кваліфікації, які виявляють бажання навчатися за дистанційною і очно-дистанційною формами, закладами післядипломної освіти України створено потужний інформаційний і навчальний ресурс, розміщений на відповідних платформах web-сайтів і зручний для користування [8]; [9]; [7, c. 142].

\section{1. Основні напрями реформування післядипломної освіти в Україні в умовах її інформатизації}

Отже, розроблення нових підходів до організації післядипломної освіти на основі принципу відкритості дозволяе гідно зустріти виклики інформаційного суспільства й відреагувати на трансформацію освітнього запиту щодо підготовки фахівців високої якості, вмотивованих на ефективну діяльність в умовах динамічних змін за різних, навіть несприятливих умов. Ці ідеї спонукають до суттєвого переформатування існуючої системи післядипломної педагогічної освіти в Україні, переходу іiї до відкритого типу, активного застосування мережних технологій, відкритого формування структури й обсягів професійної підготовки фахівців і підвищення їх кваліфікації.

Метою модернізації вітчизняної післядипломної педагогічної освіти є підготовка педагогічних працівників до професійної діяльності в постіндустріальному глобалізованому суспільстві, що вимагає від них умінь продукування проривних знань $\mathrm{i}$ 
практичного застосування інноваційних технологій 3 метою здобуття переваг у конкуренції на ринку освітніх послуг.

До основних напрямів реформування системи післядипломної педагогічної освіти (ППО) в Україні відносимо, перш за все, приведення іiї сутності і змісту у відповідність із сучасними світовими тенденціями ії розвитку, зумовленими цивілізаційними змінами і викликами, а також набуття нею спроможності давати на них адекватні відповіді.

Можливою моделлю розв'язання цього завдання може бути: «цивілізаційна зміна - освітня проблема - пошук шляхів і розроблення програми іiі вирішення відображення їх у змісті і формах ППО - акредитація і реалізація відповідних варіативних, диверсифікованих за змістом і профілями освітніх програм - моніторинг якості їх реалізації» [10, с. 18].

Безперечно, для успішного упровадження цих ідей і перетворення післядипломної освіти України на відкриту систему має ефективно працювати державна програма «Інформаційне суспільство», яка забезпечує реальну фінансову, матеріальну й нормативно-правову підтримку інформатизації вітчизняної післядипломної освіти, сприяє підвищенню індексів розвитку ІКТ в освітній сфері і уможливлює втілення прогностичних ідей відкритої післядипломної освіти на практиці [1].

До найбільш важливих і перспективних напрямів розбудови національної системи відкритої післядипломної педагогічної освіти відносимо:

- підвищення iї якості шляхом іiї фундаменталізації, застосування нових підходів, використання нових інформаційних технологій;

- забезпечення випереджувального характеру післядипломної педагогічної освіти, посилення іï спрямованості на урахування і розв'язання проблем майбутньої постіндустріальної цивілізації;

- широке використання можливостей відкритого навчання і самоосвіти суб' єктів освітнього процесу із застосуванням інформаційних і телекомунікаційних технологій, що сприятиме більшій доступності освітніх послуг, які надаються закладами післядипломної педагогічної освіти;

- упровадження розвивального підходу у післядипломній педагогічній освіті, орієнтацію іiі на розвиток креативності та адаптивності освітян у процесі їхньої перепідготовки та підвищення кваліфікації;

- утворення відкритих університетів - закладів вищої освіти нової формації, у яких використовується принципово нова технологія навчання, що передбачає наявність адміністративного ядра й мережі освітніх центрів. Така організація створює умови для функціонування відкритого університету як «розподільчого університету» в системі відкритої післядипломної педагогічної освіти, який організовує й координує роботу його структурних підрозділів, надає їй системності, а також забезпечує єдність i високий рівень вимог до надання усіх видів освітніх послуг. Завдяки створенню відкритих університетів і підтримці їх державою система післядипломної освіти в багатьох країнах світу перетворилася на координаційний центр професіоналізації педагогічних кадрів.

\section{2. Переваги відкритих університетів післядипломної освіти}

Що отримає Україна, створивши університети відкритого типу?

По-перше - забезпечення дотримання конституційних прав кожного громадянина на освіту; ліквідацію соціальної нерівності у системі освіти через рівний доступ усіх бажаючих до навчання, незалежно від соціальної, етнічної, релігійної та гендерної приналежності; реалізацію ідеї безперервного навчання протягом усього життя людини; сприяння залученню до навчання іноземної і української молоді, у тому числі, 
iз діаспор (за межами України проживає близько 11 млн. 600 тис. українців).

По-друге, це значною мірою стримуватиме відтік молоді за кордон, у рази збільшить кількість студентів у вітчизняних закладах вищої освіти; сприятиме скороченню бюджетних витрат, забезпечить сучасними знаннями значну частину дорослого населення країни, що однозначно позитивно вплине на зростання економічного потенціалу України та демографічні процеси. Створення у системі освіти дорослих відкритого університету європейського типу, навіть в умовах обмеженого фінансування, протягом 2-3 років може повністю і кардинально змінити ситуацію як в освіті, так і в суспільстві в цілому. Адже на макрорівні освіта повинна розглядатися державою у різних аспектах: як соціальний та науковий інститут, як науковий i соціальний процес, як соціальна система, соціальна та суспільна організація, а також, як взаємодія цього інституту 3 іншими інститутами, організаціями, системами, процесами, структурами, суспільством і державою в цілому [10, с. 22-23].

Основними завданнями створення відкритих університетів післядипломної освіти $\epsilon$ :

- встановлення мережної взаємодії учасників освітнього процесу;

- сприяння їм в обміні інноваційними ідеями й у самостійному здобутті необхідних знань 3 інформаційних технологій, основ менеджменту, культурної та освітньої політики тощо;

- створення єдиного інформаційного, освітнього, наукового та методичного простору;

- координація і просування освітніх стартапів у рамках діяльності спільних мережних ресурсних центрів;

- неперервний розвиток інформаційних та інших компетентностей фахівців;

- залучення їх до участі у міжнародних освітньо-наукових та управлінських проектах та ін.

Створивши відкритий університет післядипломної освіти, ми додамо динамізму розвитку цій освітній галузі в Україні, сприятимемо її «перезавантаженню» і адекватно відповімо на глобалізаційні виклики вітчизняній післядипломній освіті стосовно забезпечення інформаційної культури і якісного професійного рівня ії̈ працівників.

\section{5. ВИСНОВКИ ТА ПЕРСПЕКТИВИ ПОДАЛЬШИХ ДОСЛІДЖЕНЬ}

Узагальнення викладеного у статті дозволяє зробити такі висновки.

Формування інформаційного суспільства як нової форми соціальної дійсності зумовлює інтелектуалізацію освіти й перетворення іiі на теорію i практику неперервного професійного розвитку когнітивних працівників, здатних самостійно опрацьовувати інформацію і здобувати нове знання на основі використання інформаційно-комунікаційних технологій.

Стрімке і динамічне оновлення знань і технологій в інформаційному суспільстві актуалізує значення післядипломної освіти як системи, що забезпечує професійну мобільність i конкурентоспроможність фахівців на ринку праці, розвиває їхню адаптивність до перманентних змін інформаційного ландшафту, підвищує їх інформаційну культуру. Ефективне функціонування післядипломної освіти в інформаційному суспільстві забезпечується завдяки набуттю нею відкритості, варіативності і гнучкості, здатності створювати оптимальні умови для індивідуалізації освітнього процесу.

Соціальною місією відкритої післядипломної освіти $\epsilon$ випереджувальна підготовка фахівців до ефективної участі в професійному і громадському житті в умовах інформаційного суспільства, допомога їм у постійному підтриманні 
професійного рівня і конкурентоспроможності на ринку праці.

Проведений SWOT-аналіз дозволяє стверджувати, що переваги відкритої післядипломної освіти полягають у:

- забезпеченні оптимальних умов для раціональної й економічно вигідної організації та індивідуалізації освітнього процесу на засадах поєднання формальної, неформальної та інформальної освіти;

- створенні інноваційного навчально-пізнавального середовища, у центрі якого $\epsilon$ фахівець, який самостійно планує, програмує і реалізує проект власного професійного розвитку на засадах якнайповнішого розкриття свого творчого потенціалу й індивідуальних здібностей;

- урізноманітненні форм навчання 3 використанням різних сертифікованих платформ, індивідуальних і групових форм навчання, інтерактивних тестів для перевірки успішності, форумів для обговорення ключових питань, проведення вебінарів і масових наукових заходів on-line, які дають фахівцям можливість успішно навчатися, використовуючи найбільш зручний для них час, місце та обладнання.

Проблеми і загрози, з якими можуть у майбутньому стикнутися споживачі освітніх послуг у закладах відкритої післядипломної освіти, пов'язані з тим, що ці заклади стануть переважно віртуальними й навчання у них здійснюватиметься за моделлю «тільки ти - і комп'ютер», у якій міжособистісне спілкування педагогів і тих, хто навчається, може бути підмінене лише одним з його аспектів - комунікацією. Це зумовлює необхідність уточнення правил і норм професійної і комунікативної етики, а також функцій і сутності самого спілкування в інформаційному суспільстві.

Модернізація вітчизняної післядипломної педагогічної освіти вимагає набуття нею відкритості й спрямованості на підготовку педагогічних працівників до професійної діяльності в постіндустріальному глобалізованому світі.

Перспективними напрямами реформування системи післядипломної педагогічної освіти України на засадах забезпечення іiі відкритості є: підвищення іiі якості,

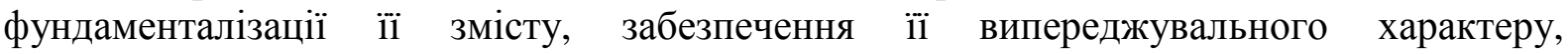
використання нових інформаційних технологій та можливостей відкритого навчання, утворення відкритих університетів - закладів типу розподільчого університету, де використовується принципово нова технологія навчання, що передбачає наявність адміністративного ядра й мережі освітніх центрів. Такі заклади об'єднують навколо себе інші заклади і $є$ координаційними центрами професіоналізації педагогічних кадрів і соціокультурними центрами національного чи регіонального значення.

Перебудова системи післядипломної освіти України на засадах забезпечення ії відкритості і мережної взаємодії структурних компонентів створить умови для перетворення її на стратегічний ресурс розвитку національної освіти в інформаційному суспільстві й сприятиме здобуттю нею гідного місця на європейському ринку освітніх послуг.

3 огляду на це, перспективи подальших наукових досліджень пов'язуються нами 3 виявленням організаційно-педагогічних умов i механізмів формування єдиного інформаційного середовища відкритих університетів 3 урахуванням зарубіжного досвіду організації такої діяльності.

\section{СПИСОК ВИКОРИСТАНИХ ДЖЕРЕЛ}

[1] М. Кириченко, Формування ідеологї інформаційного суспільства в умовах глобальної інформатизаціï: тенденції, парадигми, перспективи розвитку. Харків, Україна: Вид-во ПП «Технологічний центр», 2017.

[2] О. Отич, "Інформаційно-комунікаційні технології у забезпеченні якості освіти в суспільстві знань", 
Management of higher education quality: problems and prospects, Вип. 1., с. 36-39, 2017.

[3] В. Кремень, Світ знання: людина, наука, освіта, Київ, Україна: Знання, 2016.

[4] М. Згуровський, "Шлях до інформаційного суспільства - від Женеви до Тунісу", Дзеркало тижня, № 34 (562), 3-9 вересня, с. 4-6, 2005.

[5] О. Отич, "Освіта дорослих у суспільстві знань", Освіта дорослих у перспективі змін: інновації, технологї, прогнози, А. Василюк, А. Стоговський, Ред. Ніжин: Видавець ПП Лисенко М. М., с. 3147, 2017.

[6] В. Олійник, Відкрита післядипломна педагогічна освіта $і$ дистанційне навчання в запитаннях $i$ відповідяx, Київ, Україна: А.С.К., 2013.

[7] В. Кремень та ін. Національна доповідь про стан і перспективи розвитку освіти в Україні. Київ, Україна: Пед. думка, 2016.

[8] В. Биков, Моделі організаційних систем відкритої освіти. Київ, Україна: Атіка, 2008.

[9] В. Лапінський, А. Пилипчук, М. Шишкіна, Засоби інформаційно-комунікаційних технологій єдиного інформаційного простору системи освіти Украӥни. В. Биков, Ред. Київ, Україна: Пед. думка, 2010.

[10] В. Олійник, О. Отич, Післядипломна педагогічна освіта в контексті глобальних цивілізаційних змін, Вища освіта України в умовах глобалізації суспільства, М. Євтух, Ред. Київ, Україна: Агроосвіта, с. 9-30. 2015.

Матеріал надійшов до редакиії 30.05.2018 p.

\title{
ПРОБЛЕМЫ И ПЕРСПЕКТИВЫ РАЗВИТИЯ ПОСЛЕДИПЛОМНОГО ОБРАЗОВАНИЯ В ИНФОРМАЦИОННОМ ОБЩЕСТВЕ
}

\author{
Кириченко Николай Алексеевич \\ доктор философии, член-корреспондент Академии наук высшего образования Украины, ректор \\ ГВУЗ «Университет менеджмента образования» НАПН Украины, г. Киев, Украина \\ ORCID ID 0000-0003-1756-9140 \\ kmumo@umo.edu.ua
}

\section{Отыч Елена Николаевна}

доктор педагогических наук, профессор, проректор по научно-методической работе и международным связям ГВУЗ «Университет менеджмента образования» НАПН Украины, г. Киев, Украина ORCID ID 0000-0003-2686-2832 ndi-direktor@ukr.net

\section{Олейник Виктор Васильевич}

доктор педагогических наук, профессор, действительный член НАПН Украины, советник ректора ГВУЗ «Университет менеджмента образования» НАПН Украины, г. Киев, Украина ORCID ID 0000-0002-2576-0722

vikt.oliynyk@gmail.com

\begin{abstract}
Аннотация. Формирование информационного общества как новой формы социальной действительности, которая функционирует через посредничество мультизнаков - символов - сигналов - стимулов - кодов, стимулирует все возрастающую интеллектуализацию всех видов общественной практики, в частности, образования, которое превращается в теорию и практику непрерывного профессионального развития когнитивных работников, способных самостоятельно обрабатывать информацию и приобретать новое знание на основе использования информационно-коммуникационных технологий. Основными направлениями реформирования образования в Украине являются приведение его сущности и содержания в соответствие с современными мировыми тенденциями его развития, обусловленными цивилизационными изменениями и вызовами, а также приобретение им способности давать на них адекватные ответы.

На основе обобщения научной литературы по проблеме развития образования в информационном обществе и анализа современных тенденций усовершенствования системы последипломного образования в Украине в статье проведен SWOT-анализ развития этой образовательной отрасли в условиях её информатизации, индивидуализации и интеграции в европейское информационное образовательное пространство. Целью статьи является определение проблем, преимуществ, угроз и перспектив информатизации
\end{abstract}


отечественного последипломного образования и превращения его в открытую систему. По результатам исследования сделано вывод, что эффективное функционирование последипломного образования в открытом информационном образовательном пространстве обеспечивается благодаря приобретению ею вариативности, гибкости, способности создавать оптимальные условия для индивидуализации образовательного процесса на основе соединения формального, неформального. Доказано, что такие условия наиболее оптимально обеспечиваются в открытом университете последипломного образования.

Определены перспективные направления и задачи построения национальной системы открытого последипломного педагогического образования в Украине, предложена модель этого процесса: «цивилизационное изменение - образовательная проблема - поиск путей и разработка программы её решения - отражение их в содержании и формах последипломного образования - аккредитация и реализация соответствующих вариативных, диверсифицированных по содержанию и профилям образовательных программ - мониторинг качества их реализации».

Ключевые слова: последипломное образование; информационное общество; открытое образование; модернизация; информатизация; информационные технологии; SWOT-аналіз.

\title{
PROBLEMS AND PROSPECTS OF POSTGRADUATE EDUCATION DEVELOPMENT IN THE INFORMATION SOCIETY
}

\author{
Mykola O. Kyrychenko \\ $\mathrm{PhD}$, Corresponding Member of the Academy of Sciences of Higher Education of Ukraine, Rector o \\ SHEI "University of Educational Management" of NAES of Ukraine, Kyiv, Ukraine \\ ORCID ID 0000-0003-1756-9140 \\ kmumo@umo.edu.ua
}

Olena M. Otych

Dr.hab.of Pedagogical Sciences, Professor,

Vice-rector for Scientific and Methodological work and International Relations Department

SHEI «University of Educational Management» of NAES of Ukraine, Kyiv, Ukraine

ORCID ID 0000-0003-2686-2832

ndi-direktor@ukr.net

\section{Victor V. Oliynyk}

Dr.hab.of Pedagogical Sciences, Professor, Member of NAES of Ukraine (Academician), Adviser for Rector SHEI "University of Educational Management" of NAES of Ukraine, Kyiv, Ukraine

ORCID ID 0000-0002-2576-0722

vikt.oliynyk@gmail.com

\begin{abstract}
Formation of the information society as a new form of social reality functioning by means of multi-indicators - symbols - signals - stimulus - codes stimulates the ever-increasing intellectualization of all types of social practices, including education. It undergoes the process of transformation into a theory and practice of continuous professional development of cognitive workers capable of self-processing information and acquiring new knowledge based on using IT. The main areas of reforming education in Ukraine is to bring its essence and content into line with the contemporary development world trends, caused by civilizational changes and challenges, as well as its ability to provide adequate responses to them.

Based on a synthesis of scientific literature on the educational development in the information society and analysis of the current trends in the development of the postgraduate education system in Ukraine, the article provides SWOT analysis of the development of this educational branch in the conditions of its informatization, individualization and integration into the European information educational space. The purpose of the article is to identify the problems, advantages, threats and prospects of informatization of the national postgraduate education and transforming it into an open system. The study concluded that the effective functioning of postgraduate education in the open information educational space is ensured by its variability, flexibility, and the ability to create optimal conditions for the individualization of the educational process based on a combination of formal, informal and informal education. An open university of postgraduate education is proved to provide such conditions most optimally.
\end{abstract}


The perspective directions and development goals of the national system of open postgraduate pedagogical education in Ukraine are determined. The following model of this process is introduced: "civilization change - educational problem - search for ways and development of a program for its solution - displaying them in the content and forms PPE - accreditation and implementation of the corresponding educational programs varied in diversity of their content and profiles - monitoring the quality of their implementation."

Keywords: postgraduate education; information society; open education; modernization; informatization; information technology; SWOT-analysis.

\section{REFERENCES (TRANSLATED AND TRANSLITERATED)}

[1] M. Kyrychenko, Ideology of the information society formation in the conditions of global informatization: trends, paradigms, prospects of development, Kharkiv, Ukraina: Vid-vo PP "Technologichniy Centr", 2017 (in Ukrainian).

[2] O. Otych, "Information and communication technologies in ensuring the quality of education in the knowledge society ", Management of higher education quality: problems and prospects, Issue 1., p. 3639, 2017(in Ukrainian).

[3] V. Kremen, The world of knowledge: a man, science and education, Kyiv, Ukraina: Znannia, 2016 (in Ukrainian).

[4] M. Zgurovskiy, "The road to the information society - from Geneva to Tunis", Dzerkalo Tyzhnya, № 34 (562), September 3-9, p. 4-6, 2005 (in Ukrainian).

[5] O. Otych, "Adult education in the knowledge society", Education of adults in the change perspective: innovations, technologies, forecasts, A. Vasylyuk, A. Stogovskiy (Ed.), Nizhyn: PP Lysenko M. M., p. 31- 47, 2017 (in Ukrainian).

[6] V. Oliynyk, Open postgraduate pedagogical education and distance learning in questions and answers, Kyiv, Ukraina: A.C.K., 2013 (in Ukrainian).

[7] V. Kremen et. al., National report on the state and prospects of education in Ukraine, Kremen (Ed.), Kyiv, Ukraina: Pedagogichna Dumka, 2016 (in Ukrainian).

[8] V. Bykov, Models of Organizational Systems of Open Education. Kyiv, Ukraina: Atika, 2008 (in Ukrainian).

[9] V. Lapinskiy, A. Pilipchuk, M. Shishkina, Means of information and communication technologies of an integrated information space of the education system of Ukraine, V. Bykov (Ed.), Kyiv, Ukraina: Pedagogichna Dumka, 2010 (in Ukrainian).

[10] V. Oliynyk, O. Otych, Postgraduate pedagogical education in the context of global civilizational change, Higher education of Ukraine in the conditions of globalization of society, M. Yevtukh (Ed.), Kyiv, Ukraina: Agroosvita, p. 9-30. 2015 (in Ukrainian).

\section{(c) BY-NC-SA}

This work is licensed under Creative Commons Attribution-NonCommercial-ShareAlike 4.0 International License. 